OPEN ACCESS

Edited by:

Julia Ribeiro,

Rice University, United States

Reviewed by:

Kristina J. Walowski,

Middlebury College, United States

Philip Pogge von Strandmann,

University College London, United Kingdom

*Correspondence: Aaron W. Brewer aaronwb@uw.edu

Specialty section

This article was submitted to Geochemistry

a section of the journa

Frontiers in Earth Science

Received: 05 December 2017

Accepted: 26 February 2018

Published: 12 March 2018

Citation:

Brewer AW, Teng F-Z and Mullen E (2018) Magnesium Isotopes as a Tracer of Crustal Materials in Volcanic Arc Magmas in the Northern Cascade Arc. Front. Earth Sci. 6:21 doi: 10.3389/feart.2018.00021

\section{Magnesium Isotopes as a Tracer of Crustal Materials in Volcanic Arc Magmas in the Northern Cascade Arc}

\author{
Aaron W. Brewer ${ }^{1,2 *}$, Fang-Zhen Teng ${ }^{1}$ and Emily Mullen ${ }^{3}$ \\ ${ }^{1}$ Department of Earth and Space Sciences, University of Washington, Seattle, WA, United States, ${ }^{2}$ Biosciences and \\ Biotechnology Division, Physical and Life Sciences Directorate, Lawrence Livermore National Laboratory, Livermore, CA, \\ United States, ${ }^{3}$ Laboratoire Magmas et Volcans, Université Clermont Auvergne, Clermont-Ferrand, France
}

Fifteen North Cascade Arc basalts and andesites were analyzed for Mg isotopes to investigate the extent and manner of crustal contributions to this magmatic system. The $\delta^{26} \mathrm{Mg}$ of these samples vary from within the range of ocean island basalts (the lightest being $-0.33 \pm 0.07 \%$ ) to heavier compositions (as heavy as $-0.15 \pm 0.06 \%$ ). The observed range in chemical and isotopic composition is similar to that of other volcanic arcs that have been assessed to date in the circum-pacific subduction zones and in the Caribbean. The heavy Mg isotope compositions are best explained by assimilation and fractional crystallization within the deep continental crust with a possible minor contribution from the addition of subducting slab-derived fluids to the primitive magma. The bulk mixing of sediment into the primitive magma or mantle source and the partial melting of garnet-rich peridotite are unlikely to have produced the observed range of $\mathrm{Mg}$ isotope compositions. The results show that $\mathrm{Mg}$ isotopes may be a useful tracer of crustal input into a magma, supplementing traditional methods such as radiogenic isotopic and trace element data, particularly in cases in which a high fraction of crustal material has been added.

Keywords: magnesium isotopes, assimilation and fractional crystallization, North Cascade Arc, arc volcanism, subduction zone

\section{INTRODUCTION}

Volcanic arcs involve significant crust-mantle interactions, particularly through assimilation and fractional crystallization as magma rises to the surface and/or the addition of subducted sediment, altered oceanic crust, and slab-derived fluids to the mantle source or the primitive magma (Kelemen et al., 2007; Plank, 2014). This varied crustal material can be a major determinant of the final composition of these igneous rocks. Quantifying the crustal contribution to these magmas, and the mechanism(s) by which these materials were added, informs our understanding of the petrogenetic history of volcanic arcs, motivating the development of chemical tracers of these processes.

The unique systematics of $\mathrm{Mg}$ isotopes in mantle and crustal materials offer a new approach for tracing crustal additions to arc magmas. With a few exceptions, most significant $\mathrm{Mg}$ isotope fractionation occurs at the low temperatures of Earth's surface, while little fractionation occurs at high temperatures and pressures (Teng, 2017 and references therein). The $\mathrm{Mg}$ isotope compositions of uncontaminated mid-ocean ridge basalts and of the mantle are $\delta^{26} \mathrm{Mg}=-0.25 \pm 0.07$ and $-0.25 \pm 0.04 \%$, respectively (Teng et al., 2010a). Large deviations from the well-constrained mantle $\mathrm{Mg}$ isotope composition in an unweathered mafic rock may be indicative of crustal input 
to the magma. Surface material displays a wide range of $\delta^{26} \mathrm{Mg}$ values, from -5.57 to $+1.81 \%$, reflecting the variety of fractionation mechanisms possible at low temperatures (Teng, 2017). During chemical weathering, for example, light isotopes are preferentially removed from a rock, which in combination with variations in watershed lithology, produces isotopically light river (Pogge von Strandmann et al., 2008; Tipper et al., 2008; Teng et al., 2010b; Huang et al., 2012) and ocean water $(-0.83 \pm$ 0.07\% ; Foster et al., 2010; Ling et al., 2011). The residual silicate rock and sediment is typically isotopically heavy due to these same processes (as heavy as $+1.81 \%$; Tipper et al., 2008, 2010; Li et al., 2010; Teng et al., 2010b; Liu et al., 2014). This chemical weathering and other associated processes, such as carbonate precipitation, have produced an extremely heterogeneous upper crust in regard to $\mathrm{Mg}$ isotopes, and the subduction of this material has also resulted in isotopically heterogeneous lower crust and mantle wedge material (Li et al., 2010; Teng et al., 2013; Yang et al., 2016; Wang et al., 2017).

Recent investigations into the $\mathrm{Mg}$ isotope systematics of volcanic arc systems in the circum-Pacific subduction zones and in the Caribbean have found samples with a wide range of $\mathrm{Mg}$ isotope compositions $(-0.35 \pm 0.05 \%$ o to $+0.06 \pm$ $0.04 \%$ ), which has been attributed to variable slab-derived fluid additions (Figure 1; Teng et al., 2016; Li et al., 2017). To explore the effects of crustal contamination on $\mathrm{Mg}$ isotopes in volcanic arcs, we measured 15 samples from the North Cascade Volcanic Arc, where both uncontaminated primary magma and contaminated, evolved magmas have been previously observed. These samples are geochemically well-characterized and thought to record a range of crustal content due the addition of subducted material and/or crustal assimilation during magma transport (Figure 2; Mullen and Weis, 2013, 2015; Mullen and McCallum, 2014; Mullen et al., 2017). Our results show that the $\mathrm{Mg}$ isotope compositions of these arc magmas vary from within the established values for uncontaminated mantle-derived mafic magmas to relatively heavy compositions, likely due to crustal contamination (Figure 1). The use of $\mathrm{Mg}$ isotopes as a tracer of crustal material in magma is not limited to specific sites, but could be applicable to a variety of volcanic arc settings (Teng et al., 2016; Li et al., 2017).

\section{SAMPLES}

The Cascade Arc, located on the western margin of North America, is the result of the subduction of the Juan de Fuca plate beneath the North American plate. Most of the associated magmatic rocks contain geochemical evidence for the addition of subducted material, derived from both oceanic crust and sediment, to their mantle sources (Mullen et al., 2017). In addition, some magmas assimilated continental crust during transit to the surface (Mullen et al., 2017). We choose 15 samples from the North Cascade Volcanic Arc for Mg isotope analysis in an effort to cover samples exhibiting a wide range of known crustal content, from negligible to considerable, based on trace element compositions and $\mathrm{Sr}-\mathrm{Nd}-\mathrm{Hf}-\mathrm{Pb}$ isotope data. The analyzed samples represent a range of locations and

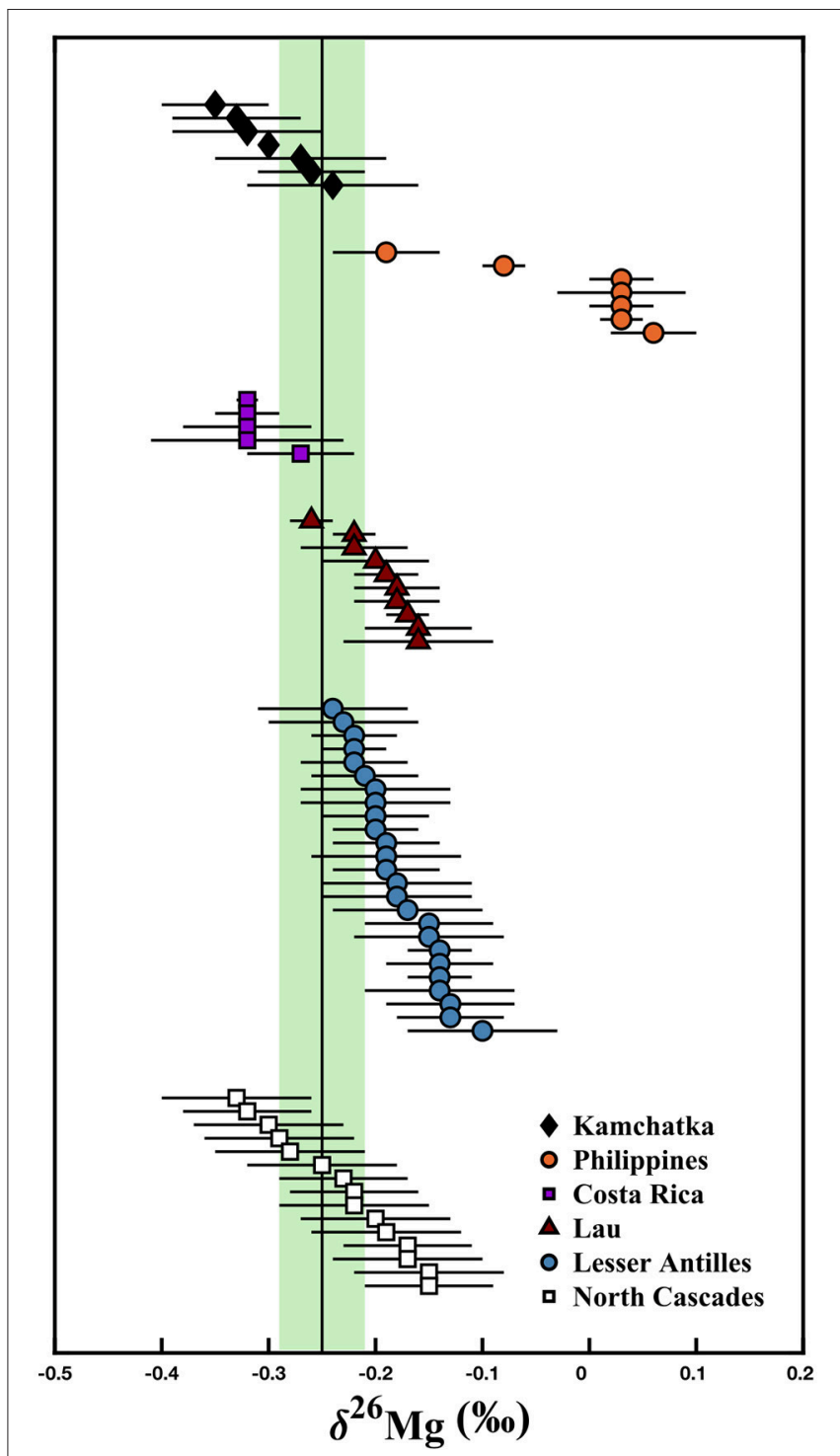

FIGURE 1 | Mg isotope composition of volcanic arc samples. Lesser Antilles data from Teng et al. (2016); Kamchatka, Philippines, Costa Rica, and Lau data from Li et al. (2017); North Cascades data from the present study. The black line and green bar represent the mantle composition based on peridotite xenoliths $\left(\delta^{26} \mathrm{Mg}=-0.25 \pm 0.04 \%\right.$ ) from Teng et al. (2010a). North Cascades data are reported in Table 1. Error bars represent the $2 S D$ for each sample.

rock types within the northern segment of the Cascade Arc, including the Mt. Baker volcanic field, the Bridge River Cones, Glacier Peak, and the Chilliwack batholith (Tepper, 1996; Mullen and Weis, 2013, 2015; Mullen and McCallum, 2014; Mullen et al., 2017). To ensure that no weathering has occurred, all samples were collected from the interior of lava flows, were confirmed to have low LOI contents $(<1 \%)$, and were examined for signs of weathering in thin section (Mullen and Weis, 2013).

The North Cascade samples fall into three petrologic groups: (1) alkali basalts from the Bridge River Cones; (2) calc-alkaline arc basalts from Mt. Baker, Glacier Peak, and the Chilliwack 

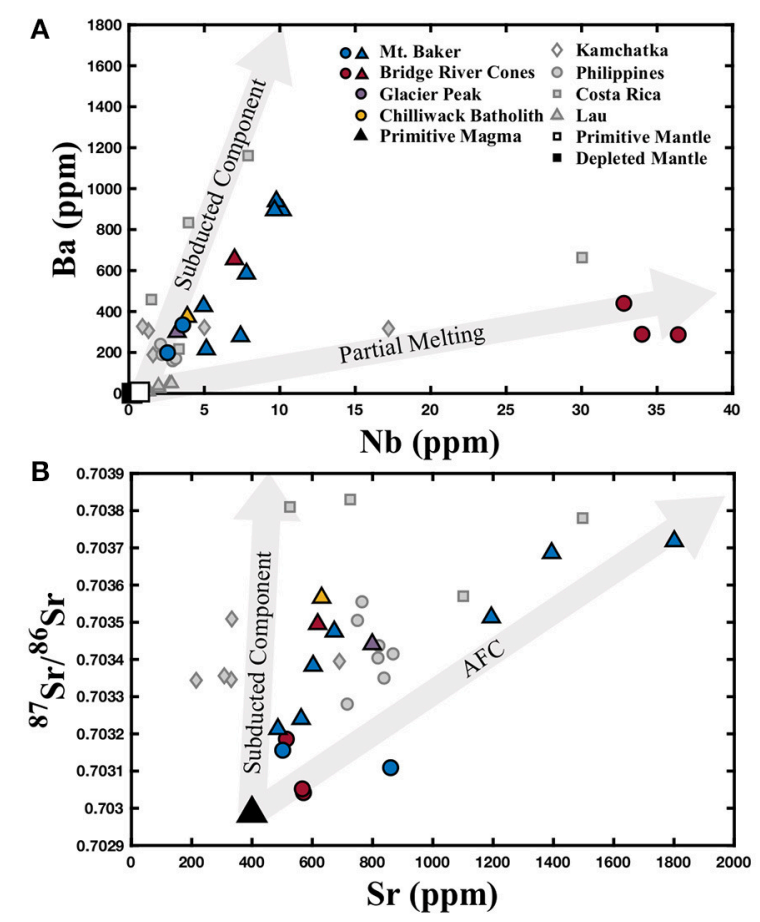

FIGURE 2 | (A) Ba and Nb contents of the North Cascades samples, as well as literature data from other volcanic arcs where available. The first labeled gray arrow approximates the effects of the addition of a subducted component (bulk sediment) prior to $10 \%$ partial melting of the depleted mantle, and the second approximates the effects of partial melting of the primitive mantle for the North Cascades based on Mullen and Weis (2013). Primitive mantle composition is from Sun and McDonough (1989). Depleted mantle composition is from Salters and Stracke (2004). (B) Sr isotope composition and Sr content of the North Cascades samples, as well as literature data from other volcanic arcs where available. The first labeled gray arrow approximates the effects of the addition of a subducted component (bulk sediment) to a primitive magma and the second approximates the effects of assimilation and fractional crystallization with a gabbro assimilant for the North Cascades based on Mullen and Weis (2013). The primitive magma composition is based on Mullen and Weis (2013). The colored circles represent those samples identified as most primitive from Mt. Baker and the Bridge River Cones, while the colored triangles represent samples that exhibit crustal contamination. North Cascades data are reported in Table 1. Literature data are represented by gray symbols and are from Li et al. (2017).

batholith; and (3) andesites from Mt. Baker and the Bridge River Cones. The alkali basalts from the Bridge River Cones display trace element and $\mathrm{Sr}-\mathrm{Nd}-\mathrm{Hf}-\mathrm{Pb}$ isotope compositions that indicate an enriched mantle source and the absence of a subducted component (Figure 2; Mullen and Weis, 2013). A slab gap between the stagnant Explorer and Juan de Fuca plates near the northern termination of the arc likely facilitated upwelling of enriched asthenosphere that produced these alkali basalts nearly free of slab input (Mullen and Weis, 2013, 2015; Mullen et al., 2017). One andesite from the Bridge River Cones does show signs of crustal assimilation, like other andesites from the North Cascades (Figure 2; Mullen and Weis, 2013). Previous work has found that the calc-alkaline basalts from Mt. Baker, Glacier Peak, and the Chilliwack batholith, as well as andesites from Mt. Baker and the Bridge River Cones, demonstrate a clear subducted component, marked by elevated abundances of lead $(\mathrm{Pb})$, large ion lithophile elements (LILE), and light rare earth elements (LREE) relative to high field strength elements (HSFE) (Figure 2; Mullen and Weis, 2013, 2015; Mullen and McCallum, 2014). Furthermore, the ${ }^{87} \mathrm{Sr} /{ }^{86} \mathrm{Sr}$ vs. Sr systematics indicate the involvement of assimilation and fractional crystallization in the deep crust in some samples (Figure 2; Mullen and Weis, 2013, 2015; Mullen and McCallum, 2014).

\section{METHODS}

Magnesium isotope analyses were performed at the Isotope Laboratory in the Department of Earth and Space Sciences at the University of Washington. All procedures are similar to those reported in previous publications (Teng et al., 2007, 2010a; Yang et al., 2009; Li et al., 2010; Teng and Yang, 2014).

The powdered rock samples were dissolved in Savillex screw-top Teflon beakers on a hotplate at $\sim 125^{\circ} \mathrm{C}$ using a 3:1 $\mathrm{HF}_{-} \mathrm{HNO}_{3}$ acid mixture followed by a 3:1 $\mathrm{HCl}-\mathrm{HNO}_{3}$ acid mixture. The samples were kept in each acid mixture for several days to ensure complete dissolution. To achieve cation separation, the samples were passed twice through a column containing Bio-Rad 200-400 mesh AG50W-X8 cation exchange resin in a $1 \mathrm{~N}^{-\mathrm{HNO}_{3}}$ media, and were eluted using $1 \mathrm{~N} \mathrm{HNO}_{3}$. The resulting $\mathrm{Mg}$ cut contains $>99 \%$ of the $\mathrm{Mg}$ in the sample to prevent isotope fractionation within the column, and limits the concentrations of the other elements to $<5 \%$ of the concentration of $\mathrm{Mg}$ (Teng et al., 2007).

The purified Mg samples were then analyzed on a Nu Plasma MC-ICP-MS using the standard-sample bracketing method. The Mg concentrations of the sample and standard solutions were matched to within $5 \%$ to prevent mass bias caused by a concentration mismatch (Teng and Yang, 2014). The solutions contained $\sim 300 \mathrm{ppb} \mathrm{Mg}$ in $3 \%$ nitric acid. The samples were introduced using the "wet" plasma method and ${ }^{24} \mathrm{Mg}$, ${ }^{25} \mathrm{Mg}$, and ${ }^{26} \mathrm{Mg}$ were analyzed simultaneously using three Faraday cups (H5, Ax, and L4). Results are presented in delta notation:

$$
\delta^{x} M g(\%)=\left[\frac{\left(\frac{{ }^{x} M g}{{ }^{24} M g}\right)_{\text {Sample }}}{\left(\frac{x^{x} M g}{{ }^{24} M g}\right)_{\text {Standard }}}-1\right] * 1000
$$

where $\mathrm{x}$ refers to mass 25 or 26.

The precision of the measured ${ }^{26} \mathrm{Mg} /{ }^{24} \mathrm{Mg}$ ratio for one sample solution at the 2 SD level, based on repeat standard analyses during a single analytical session, is $< \pm 0.07 \%$, comparable to previous $\mathrm{Mg}$ isotope studies ( $\mathrm{Li}$ et al., 2010; Teng et al., 2010a; Ling et al., 2011; Teng and Yang, 2014). The reference materials San Carlos Olivine $(n=4)$ and Seawater $(n=3)$ were each analyzed at least once during an analytical session, each time yielding a $\delta^{26} \mathrm{Mg}$ value within the established $2 \mathrm{SD}$ of -0.25 and $-0.83 \%$, respectively. These values agree 
with previously published data (Teng et al., 2015; Hu et al., 2016a).

\section{RESULTS}

Magnesium isotopic compositions, $\mathrm{MgO}$ concentrations, relevant trace element data, and $\mathrm{Sr}$ isotope compositions for the North Cascade Arc are reported in Table 1. The Mt. Baker samples range from $\delta^{26} \mathrm{Mg}=-0.32$ to $-0.15 \pm 0.06 \%$; the Bridge River Cones samples range from $\delta^{26} \mathrm{Mg}=-0.33$ to $-0.22 \pm 0.07 \%$; the $\mathrm{Mg}$ isotope composition of the Chilliwack Batholith and Glacier Peak samples is $\delta^{26} \mathrm{Mg}=-0.23$ and -0.22 $\pm 0.07 \%$, respectively. Weak correlations between $\delta^{26} \mathrm{Mg}$ and $\mathrm{MgO}$ content, ${ }^{87} \mathrm{Sr} /{ }^{86} \mathrm{Sr}$, Th/ $\mathrm{Yb}$, and $\mathrm{Pb} / \mathrm{Ce}$ may be evident in these samples, but given the number of processes that can affect the chemical and isotopic composition of arc magmas, clear correlations are not expected (Figures 3, 5). No correlation is observed between $\mathrm{Mg}$ isotope composition and $\mathrm{Ba} / \mathrm{Th}, \mathrm{Dy} / \mathrm{Yb}$, or $\mathrm{Sm} / \mathrm{Yb}$ (Figures 4, 5). The increase in $\delta^{26} \mathrm{Mg}$ from the
MORB-like composition is small; however, it is resolvable with the current precision $(\leq 0.07 \%$ o).

\section{DISCUSSION}

\section{Mg Isotope Variations in the North Cascade Volcanic Arc}

The alkali basalts from the Bridge River Cones are essentially free of crustal contamination based on trace element and $\mathrm{Sr}$ $\mathrm{Nd}-\mathrm{Hf}-\mathrm{Pb}$ isotope data; a conclusion which is supported by $\mathrm{Mg}$ isotope systematics (Figure 2; Mullen and Weis, 2013). The samples, with $\delta^{26} \mathrm{Mg}$ between -0.33 and $-0.25 \pm 0.07 \%$, fall within the range of $\mathrm{Mg}$ isotope compositions exhibited by MORBs $\left(\delta^{26} \mathrm{Mg}=-0.31\right.$ to $\left.-0.19 \%\right)$ and OIBs $\left(\delta^{26} \mathrm{Mg}=-0.35\right.$ to $-0.18 \%$ ) (Teng et al., 2010a). They do not reach the heavier compositions found elsewhere in the North Cascades, for example at Mt. Baker (Figure 3). Thus, the Mg isotope composition of these basalts supports the conclusion that the Bridge River Cones likely reflect the melting of a primitive mantle

TABLE 1 | Magnesium isotope and trace element compositions of samples and standards ${ }^{\mathrm{a}}$.

\begin{tabular}{|c|c|c|c|c|c|c|c|c|c|c|c|c|c|c|}
\hline Sample & $\begin{array}{c}\delta^{26} \mathrm{Mg} \\
(\%)\end{array}$ & $2 S D$ & $\begin{array}{c}\delta^{25} \mathrm{Mg} \\
(\%)\end{array}$ & $2 S D$ & $\begin{array}{l}\text { MgO } \\
\text { (wt\%) }\end{array}$ & $\mathrm{Sm} / \mathrm{Yb}$ & $\mathrm{Dy} / \mathrm{Yb}$ & Th/Yb & $\mathrm{Pb} / \mathrm{Ce}$ & $\mathrm{Ba} / \mathrm{Th}$ & $\begin{array}{c}\mathrm{Ba} \\
(\mathrm{ppm})\end{array}$ & $\begin{array}{c}\mathrm{Nb} \\
(\mathrm{ppm})\end{array}$ & $\begin{array}{c}\mathrm{Sr} \\
(\mathrm{ppm})\end{array}$ & ${ }^{87} \mathrm{Sr} /{ }^{86} \mathrm{Sr}$ \\
\hline \multicolumn{15}{|l|}{ NORTH CASCADE ARC } \\
\hline \multicolumn{15}{|l|}{ Mt. BAKER } \\
\hline Tarn Plateau & -0.28 & 0.07 & -0.19 & 0.06 & 7.76 & 2.199 & 2.078 & 1.295 & 0.122 & 155.8 & 335 & 3.57 & 860 & 0.703109 \\
\hline Sulfur Creek & -0.23 & 0.06 & -0.13 & 0.04 & 5.42 & 1.878 & 2.069 & 0.446 & 0.084 & 206.7 & 279 & 7.40 & 563 & 0.703240 \\
\hline Lake Shannon & -0.29 & 0.07 & -0.19 & 0.06 & 6.44 & 1.586 & 1.918 & 0.410 & 0.100 & 195.5 & 215 & 5.13 & 486 & 0.703213 \\
\hline Park Butte & -0.32 & 0.06 & -0.18 & 0.04 & 8.38 & 1.470 & 1.939 & 0.303 & 0.088 & 331.7 & 199 & 2.56 & 502 & 0.703156 \\
\hline Cathedral Crag & -0.15 & 0.07 & -0.11 & 0.06 & 3.96 & 2.944 & 2.219 & 1.163 & 0.097 & 229.0 & 426 & 4.95 & 1194 & 0.703513 \\
\hline Coleman Pinnacle 101B & -0.15 & 0.06 & -0.09 & 0.04 & 1.36 & 1.929 & 1.688 & 3.326 & 0.192 & 120.0 & 894 & 10.16 & 603 & 0.703383 \\
\hline Coleman Pinnacle 105 & -0.17 & 0.06 & -0.10 & 0.04 & 2.84 & 3.949 & 2.178 & 3.010 & 0.185 & 158.2 & 938 & 9.77 & 1801 & 0.703718 \\
\hline Coleman Pinnacle 86 & -0.20 & 0.07 & -0.08 & 0.06 & 2.59 & 3.110 & 1.991 & 2.749 & 0.187 & 148.5 & 894 & 9.65 & 1394 & 0.703686 \\
\hline Table Mountain & -0.17 & 0.07 & -0.12 & 0.06 & 3.08 & 1.963 & 1.817 & 1.846 & 0.169 & 132.1 & 585 & 7.79 & 673 & 0.703475 \\
\hline \multicolumn{15}{|l|}{ BRIDGE RIVER CONES } \\
\hline Tuber Hill East Dot & -0.22 & 0.06 & -0.08 & 0.04 & 3.44 & 2.272 & 1.685 & 1.568 & 0.173 & 257.9 & 655 & 7.0 & 618 & 0.703495 \\
\hline Tuber Hill East Cap & -0.30 & 0.07 & -0.16 & 0.06 & 4.60 & 2.928 & 2.432 & 0.808 & 0.043 & 143.1 & 289 & 34.0 & 571 & 0.703042 \\
\hline Tuber Hill East Plateau & -0.33 & 0.07 & -0.16 & 0.06 & 3.10 & 2.752 & 2.314 & 0.625 & 0.077 & 212.6 & 440 & 32.8 & 514 & 0.703186 \\
\hline Nichols Valley & -0.25 & 0.07 & -0.14 & 0.06 & 4.44 & 3.043 & 2.361 & 0.816 & 0.037 & 140.0 & 287 & 36.4 & 567 & 0.703052 \\
\hline \multicolumn{15}{|c|}{ CHILLIWACK BATHOLITH } \\
\hline Mount Sefrit & -0.23 & 0.07 & -0.09 & 0.06 & 6.80 & 2.550 & 2.015 & 1.329 & 0.164 & 161.3 & 300 & 3.19 & 799 & 0.703441 \\
\hline \multicolumn{15}{|l|}{ GLACIER PEAK } \\
\hline Dishpan Gap & -0.22 & 0.07 & -0.14 & 0.06 & 4.47 & 2.129 & 1.817 & 1.378 & 0.139 & 112.7 & 374 & 3.87 & 631 & 0.703566 \\
\hline \multicolumn{15}{|l|}{ STANDARDS } \\
\hline Seawater & -0.81 & 0.07 & -0.43 & 0.06 & & & & & & & & & & \\
\hline Replicate & -0.88 & 0.07 & -0.54 & 0.06 & & & & & & & & & & \\
\hline Replicate & -0.83 & 0.07 & -0.50 & 0.06 & & & & & & & & & & \\
\hline SC Olivine & -0.23 & 0.07 & -0.05 & 0.06 & & & & & & & & & & \\
\hline Duplicate & -0.25 & 0.07 & -0.20 & 0.06 & & & & & & & & & & \\
\hline Duplicate & -0.31 & 0.06 & -0.15 & 0.04 & & & & & & & & & & \\
\hline Replicate & -0.24 & 0.06 & -0.11 & 0.04 & & & & & & & & & & \\
\hline
\end{tabular}

${ }^{a}$ North Cascades major and trace element data from Mullen and McCallum (2013, 2014); Mullen and Weis (2015); Mullen et al. (2017). 2SD = Two standard deviation of the population of $n(15<n<22)$ repeat measurements of the standards during an analytical session. 

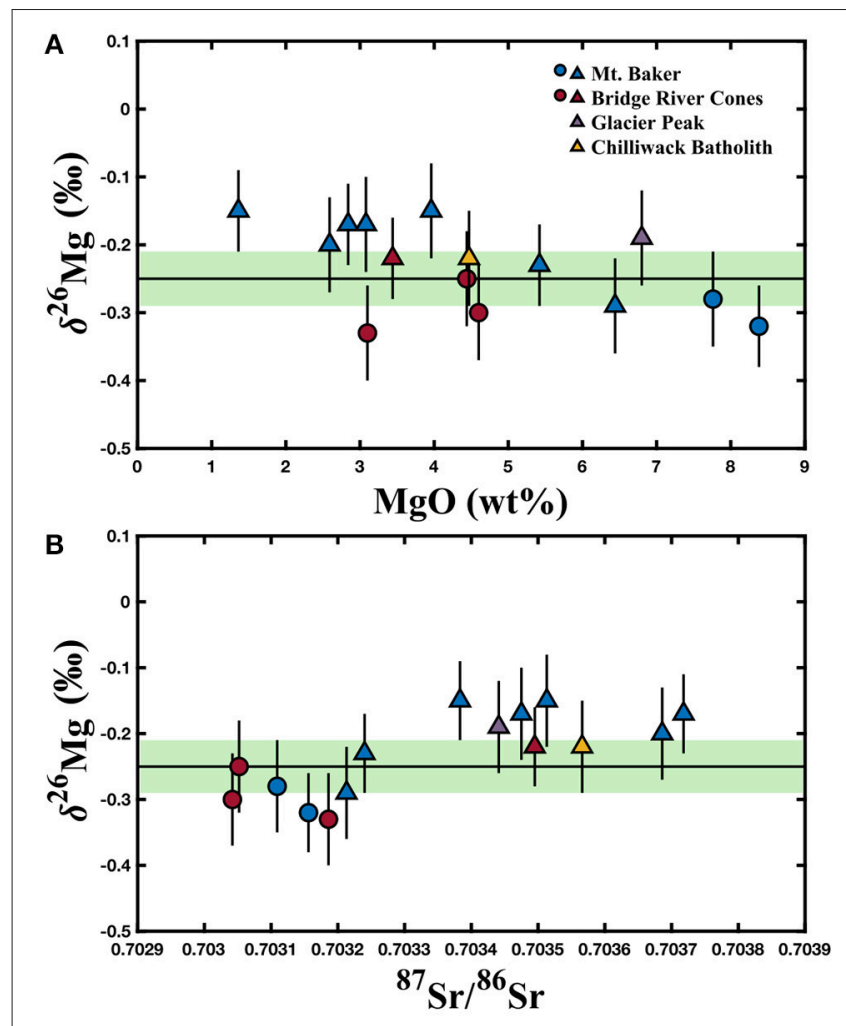

FIGURE 3 | (A) Variation of $\delta^{26} \mathrm{Mg}$ with wt\% MgO. (B) Variation of $\delta^{26} \mathrm{Mg}$ with ${ }^{87} \mathrm{Sr} / 86 \mathrm{Sr}$. The colored circles represent those samples identified as most primitive from Mt. Baker and the Bridge River Cones, while the colored triangles represent samples that exhibit crustal contamination. The black line and green bar represent the mantle composition based on peridotite xenoliths $\left(\delta^{26} \mathrm{Mg}=-0.25 \pm 0.04 \%\right)$ from Teng et al. (2010a). North Cascades data are reported in Table 1. Error bars represent the $2 S D$ for each sample.

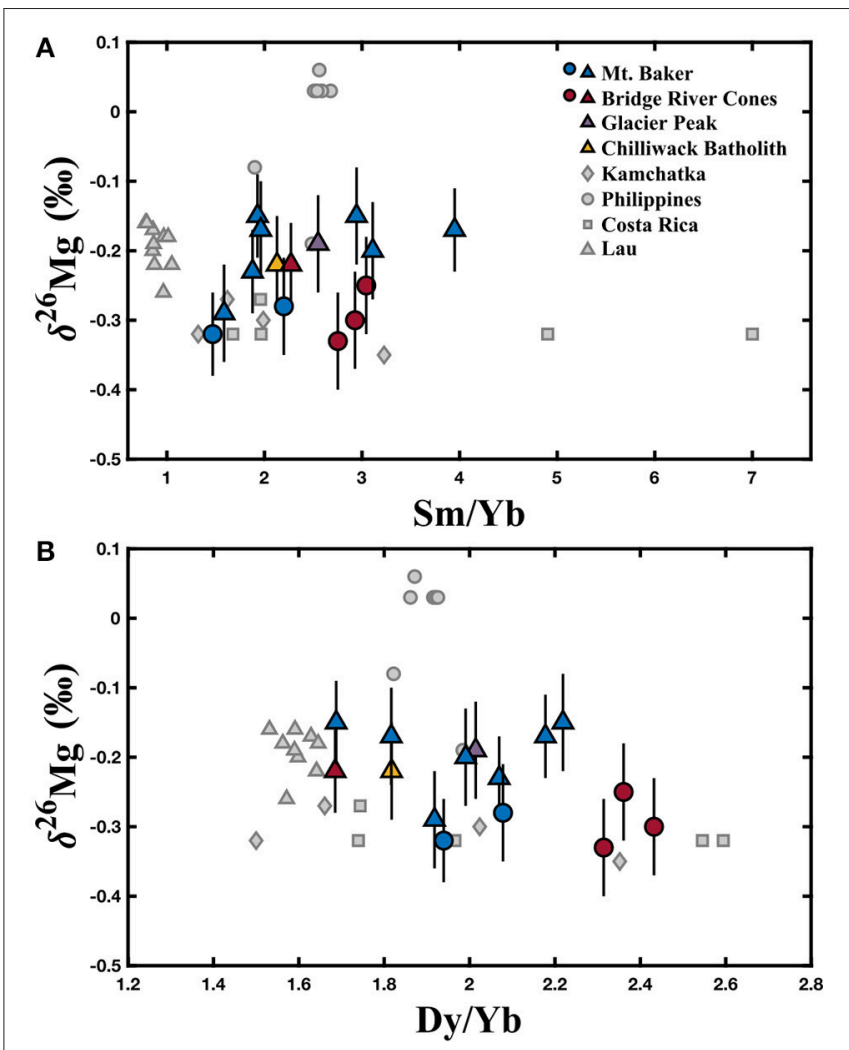

FIGURE 4 | Variation of $\delta^{26} \mathrm{Mg}$ with (A) $\mathrm{Sm} / \mathrm{Yb}$ and (B) Dy/Yb ratios. The colored circles represent those samples identified as most primitive from Mt. Baker and the Bridge River Cones, while the colored triangles represent samples that exhibit crustal contamination. North Cascades data are reported in Table 1. Literature data are represented by gray symbols and are from $\mathrm{Li}$ et al. (2017). Error bars represent the 2SD for each North Cascades sample. source with little to no contribution from subducted material or assimilated continental crust (Figure 3; Mullen and Weis, 2013).

The calc-alkaline arc basalts from Mt. Baker, Glacier Peak, and the Chilliwack batholith and the andesites from Mt. Baker and the Bridge River Cones do show the influence of subducted material and/or assimilation and fractional crystallization of the continental crust (Mullen and McCallum, 2014). While all of these samples are thought to exhibit some crustal contamination, we consider the Tarn Plateau and Park Butte samples to be the most primitive, given their high $\mathrm{MgO}$ contents ( $>7 \mathrm{wt} \%$ ), high Mg\# (>0.6), and relatively high compatible trace element content (e.g., Cr > 200 ppm; Mullen and Weis, 2013, 2015; Mullen and McCallum, 2014). The Mg isotope compositions of these samples are also quite light $(-0.28 \pm 0.07$ and $-0.32 \pm$ $0.07 \%$, respectively), similar to the primitive alkali basalts from the Bridge River Cones, which are known to contain little crustal contamination (Figure 3). The remainder of the calc-alkaline basalts and andesites display variable crustal involvement from subducted material and/or assimilated continental crust (Tepper, 1996; Mullen and Weis, 2013, 2015; Mullen and McCallum, 2014). The relatively heavy $\mathrm{Mg}$ isotope compositions of these samples likely reflects the addition of isotopically heavy crustal material, such as subducted sediment $\left(\delta^{26} \mathrm{Mg}=-3.65\right.$ to $+0.52 \%$ ), altered oceanic crust $\left(\delta^{26} \mathrm{Mg}=-2.76\right.$ to $+0.21 \%$, and deep continental crust $\left(\delta^{26} \mathrm{Mg}=-0.76\right.$ to $+0.19 \%$ ) (Figure 3; Huang, 2013; Teng et al., 2013; Yang et al., 2016; $\mathrm{Hu}$ et al., 2017). The following sections will examine the possible causes of the elevated $\mathrm{Mg}$ isotope compositions of these arc samples.

\section{Hypotheses for Mg Isotope Variations}

The observed increase in $\mathrm{Mg}$ isotope composition may be the result of one of three processes, or a combination thereof: the primary melt was derived from partial melting of garnet-rich peridotite, isotopically heavy subducted material was added to the primitive magmas or the mantle source, or the primitive magmas underwent assimilation and fractional crystallization during transport within the continental crust.

Garnet has a light $\mathrm{Mg}$ isotope composition compared to coexisting silicates (Li et al., 2011, 2016; Wang et al., 2012, 2014; Huang et al., 2013). The difference in Mg coordination between garnet (eight-fold) and most silicate minerals (sixfold) causes ${ }^{24} \mathrm{Mg}$ to be preferentially incorporated into garnet, leaving the surrounding minerals enriched in ${ }^{26} \mathrm{Mg}$ ( $\mathrm{Li}$ et al., 

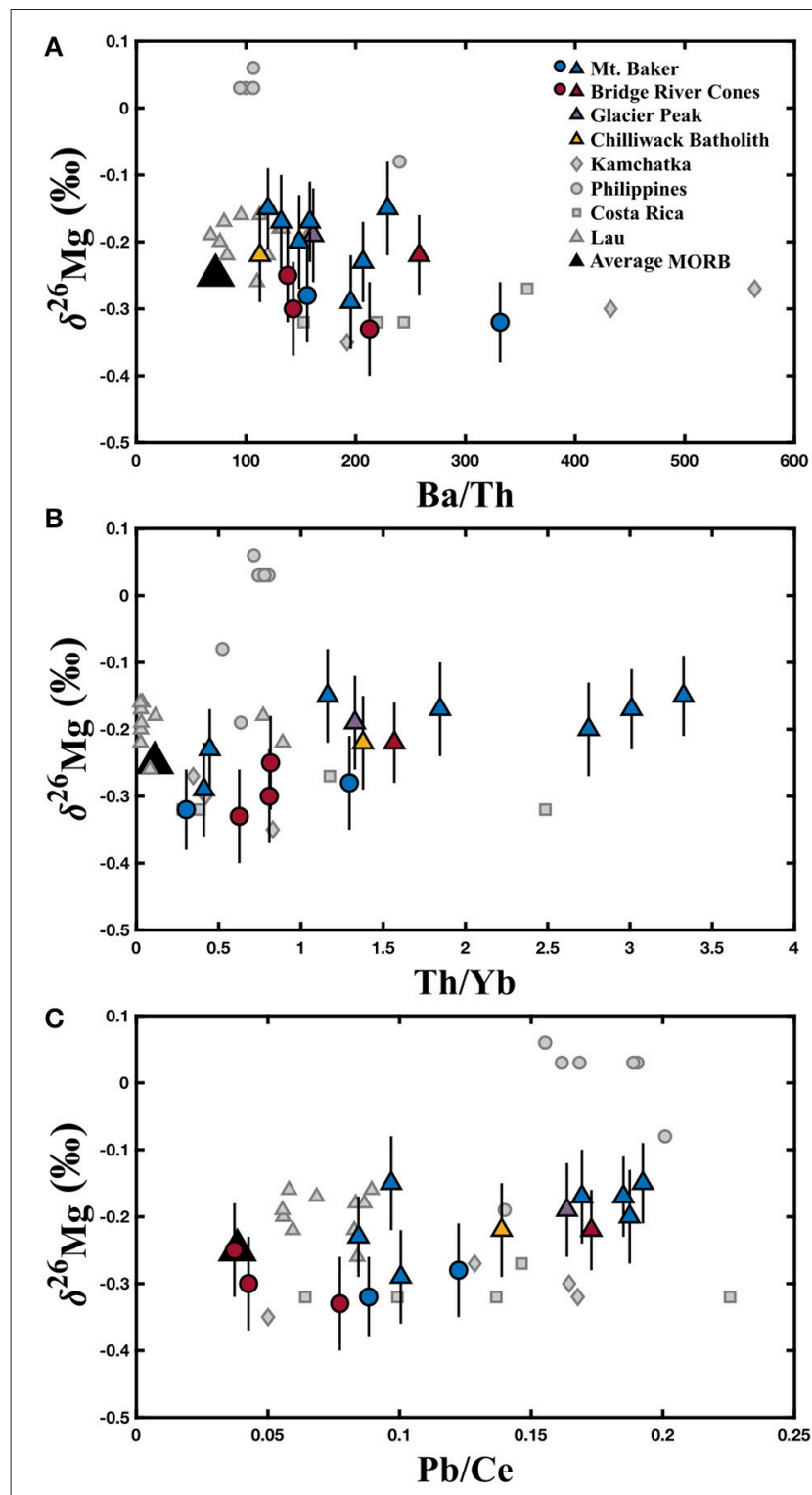

FIGURE 5 | Variation of $\delta^{26} \mathrm{Mg}$ with, $\mathrm{Ba} / \mathrm{Th}$ (A), Th/Yb (B), and Pb/Ce (C). The black triangles represent the average MORB composition. MORB $\delta^{26} \mathrm{Mg}$ value $(-0.25 \pm 0.07 \%)$ is from Teng et al. (2010a), while Th/Yb (0.1113), $\mathrm{Pb} / \mathrm{Ce}$ (0.0384), and Ba/Th (72.2772) are from Gale et al. (2013). The colored circles represent those samples identified as most primitive from Mt. Baker and the Bridge River Cones, while the colored triangles represent samples that exhibit crustal contamination. Literature data are represented by gray symbols and are from Li et al. (2017). North Cascades data are reported in Table 1. Error bars represent the $2 S D$ for each North Cascades sample.

2011, 2016; Wang et al., 2012, 2014; Huang et al., 2013). Both equilibrium and disequilibrium inter-mineral fractionation can occur between garnet and coexisting silicates (Li et al., 2016). Therefore, partial melting that leaves a garnet-rich residue could produce a melt with a relatively heavy $\mathrm{Mg}$ isotope composition. However, the trace element data do not support this explanation for the origin of the isotopically heavy magmas. Because of the affinity of the HREE for garnet, partial melts leaving a garnet-rich residue would also display relatively high $\mathrm{Sm} / \mathrm{Yb}$ and $\mathrm{Dy} / \mathrm{Yb}$ ratios (Lassiter and DePaolo, 1997). Therefore, $\delta^{26} \mathrm{Mg}$ should be positively correlated with $\mathrm{Sm} / \mathrm{Yb}$ and $\mathrm{Dy} / \mathrm{Yb}$, which is not observed in the North Cascades or any other volcanic arc assessed to date (Figure 4). Furthermore, previous work has ruled out residual garnet for Mt. Baker and Glacier Peak based on trace element modeling (Mullen and Weis, 2013, 2015). Residual garnet associated with the Bridge River Cones is likely, however, those samples do not exhibit heavy $\mathrm{Mg}$ isotope compositions (Mullen and Weis, 2013). We therefore conclude that partial melting in the presence of garnet is unlikely to have produced the observed $\mathrm{Mg}$ isotope compositions.

The addition of a crustal component to the magmas is more consistent with the $\mathrm{Mg}$ isotope data. Because crustal material, such as subducted sediment, generally has lower $\mathrm{MgO}$ contents than the mantle source and primitive magmas (McDonough and Sun, 1995; Rudnick and Gao, 2003; Plank, 2014), crustal input into a magma is generally associated with a decrease in $\mathrm{MgO}$. Fractional crystallization can produce similar changes in chemical composition; however, fractional crystallization does not fractionate $\mathrm{Mg}$ isotopes, with the exception of processes associated with garnet (Teng, 2017 and references therein). A heavy $\mathrm{Mg}$ isotope composition in these samples is also associated with increased ${ }^{87} \mathrm{Sr} /{ }^{86} \mathrm{Sr}$, which is expected given that crustal materials have elevated ${ }^{87} \mathrm{Sr} /{ }^{86} \mathrm{Sr}$ compared to most mantlederived melts (Kelemen et al., 2007; Plank, 2014). Slab-derived fluid additions to the mantle wedge are typically associated with increases in $\mathrm{Pb} / \mathrm{Ce}$ and $\mathrm{Ba} / \mathrm{Th}$ ratios, while subducted sediment melts are typically associated with increased $\mathrm{Th} / \mathrm{Yb}$ ratios. Weak correlations between $\delta^{26} \mathrm{Mg}$ and $\mathrm{Pb} / \mathrm{Ce}$ and $\mathrm{Th} / \mathrm{Yb}$ may be present in these samples, but no correlation with $\mathrm{Ba}$ /Th is observed (Figure 3). Taken together, the North Cascade Volcanic Arc samples exhibit a range of $\mathrm{Mg}$ isotope compositions that is best explained by crustal additions, rather than garnet involvement.

\section{Modeling Crustal Input}

To investigate the origin of crustal contributions to the North Cascade Arc, an AFC model (DePaolo, 1981) combining primitive magma and lower continental crust and two different two-component bulk-mixing models (primitive magma + subducted sediment and depleted mantle + subducted sediment) were constructed for the North Cascade Arc (Figure 6). The models are designed to be representative of the calc-alkaline arc basalts from Mt. Baker, Glacier Peak, and the Chilliwack batholith and the andesites from Mt. Baker and the Bridge River Cones, but not the alkali basalts from the Bridge River Cones since they are known to be petrogenetically distinct from the other samples. All end-member compositions and other model parameters are listed in Table 2.

The primitive magma composition was selected based on the samples judged to be the most primitive in the Mt. Baker dataset (Tarn Plateau and Park Butte). The depleted mantle composition is from Salters and Stracke (2004), with the exception of the $\mathrm{Mg}$ isotope composition $(-0.25 \%)$, which is the canonical mantle value described in Teng et al. (2010a) and elsewhere (Huang et al., 2011; Hu et al., 2016b; Wang et al., 2016). The lower 


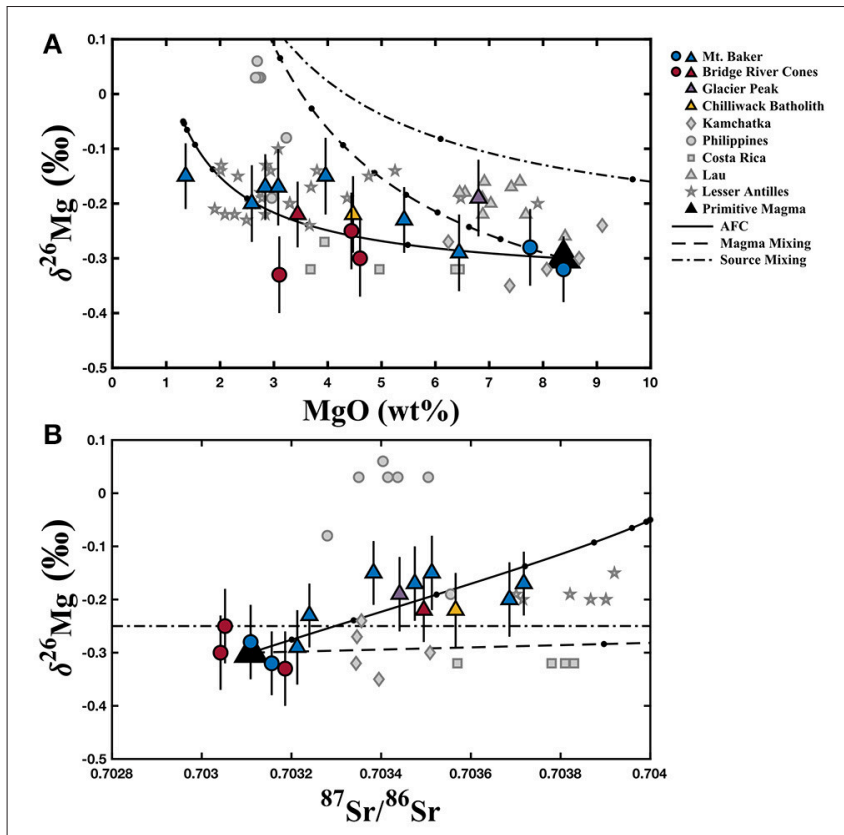

FIGURE 6 | AFC (assimilation-fractional crystallization) and bulk mixing models for $\delta^{26} \mathrm{Mg}$ vs. wt\% $\mathrm{MgO}$ (A) and ${ }^{87} \mathrm{Sr} /{ }^{86} \mathrm{Sr}$ (B) for the North Cascades samples and available literature data. The colored circles represent those samples identified as most primitive from Mt. Baker and the Bridge River Cones, while the colored triangles represent samples that exhibit crustal contamination. The dashed and dotted line represents bulk mixing between depleted mantle and subducted sediment; the dashed line represents bulk mixing between primitive magma and subducted sediment; the solid line represents assimilation and fractional crystallization of lower continental crust by the primitive magma. Table 2 contains the end-member compositions, modeling parameters, and their sources. The black circles along the modeled curves represent 10\% bulk mixing increments, and 10\% crystallization increments in the AFC model. The black triangle represents the initial primitive magma end-member. Error bars represent the 2SD for each North Cascades sample. North Cascades data are reported in Table 1. Literature data (gray symbols) are from Li et al. (2017) and Teng et al. (2016).

continental crust composition is based on the North Cascades lower crust end-member from Mullen and Weis (2013). The $\mathrm{Mg}$ isotope composition of the lower crust in this region is unknown, so a reasonable composition $(-0.05 \%$ ) was selected based on the range exhibited by lower crustal material in Yang et al. (2016). Finally, the subducted sediment end-member is based on the subducted sediment at the Cascades from Plank (2014). However, the Mg isotope composition of the subducted sediment component affecting the mantle source or primitive magma is unknown, so again a reasonable value $(+0.20 \%$ ) was selected based on $\mathrm{Hu}$ et al. (2017). For the AFC models, the ratio of assimilation to crystallization was fixed at 0.5 , and the bulk partition coefficients for $\mathrm{MgO}$ and $\mathrm{Sr}$ were estimated and fixed at 3.0 and 3.2, respectively, after the volcanic arc modeling of Teng et al. (2016). Minor changes in the bulk partition coefficients have little impact on the model. Although some of the relevant modeling parameters can only be estimated, these models do demonstrate that AFC is a feasible explanation for the observed data, while bulk mixing alone is not.
TABLE 2 | Modeling parameters and end-member compositions.

\begin{tabular}{|c|c|c|c|c|}
\hline Sample & $\begin{array}{c}\delta^{26} \mathrm{Mg} \\
(\%)\end{array}$ & $\begin{array}{l}\text { MgO } \\
\text { (wt\%) }\end{array}$ & $\begin{array}{c}\mathrm{Sr} \\
(\mathrm{ppm})\end{array}$ & ${ }^{87} \mathrm{Sr} /{ }^{86} \mathrm{Sr}$ \\
\hline \multicolumn{5}{|c|}{ END-MEMBER COMPOSITIONS } \\
\hline Depleted mantle & $-0.25^{a}$ & $38.2^{d}$ & $9.8^{d}$ & $0.70260^{d}$ \\
\hline Primitive magma & -0.30 & 8.38 & 502 & 0.70311 \\
\hline Lower crust & $-0.05^{b}$ & $6.57^{e}$ & $401^{e}$ & $0.70400^{\mathrm{e}}$ \\
\hline Subducted sediment & $+0.20^{c}$ & $2.53^{f}$ & $323^{f}$ & $0.71490^{f}$ \\
\hline \multicolumn{5}{|c|}{ MODELING PARAMETERS } \\
\hline $\mathrm{D}_{\mathrm{Sr}}$ & $3.2^{\mathrm{g}}$ & & & \\
\hline $\mathrm{D}_{\mathrm{MgO}}$ & $3.0^{9}$ & & & \\
\hline r & $0.5^{9}$ & & & \\
\hline
\end{tabular}

a Teng et al. (2010a).

byang et al. (2016).

${ }^{c}$ Hu et al. (2017).

${ }^{d}$ Salters and Stracke (2004).

eMullen and Weis (2013).

${ }^{f}$ Plank (2014).

gTeng et al. (2016).

The North Cascade Arc two-component bulk mixing models are unable to reproduce the observed trends in the data, particularly the $\mathrm{Sr}$ isotope compositions. To approximate the $\mathrm{MgO}$ content and $\mathrm{Mg}$ isotope composition of some North Cascades samples with the primitive magma mixing model, the sediment must contribute more than $50 \%$ of the final magma, which is unreasonably high (Figure 6A). The $\mathrm{Sr}$ and $\mathrm{Mg}$ isotope primitive magma mixing model predicts very little change in $\mathrm{Mg}$ isotope composition across the whole range of $\mathrm{Sr}$ isotope compositions observed in the samples, which does not agree with the observed data (Figure 6B). The two-component mantle source mixing model requires an even higher fraction of crustal material (more than 80\%) to produce the observed $\mathrm{Mg}$ isotope compositions given the high $\mathrm{MgO}$ content of the mantle, and again no change in $\mathrm{Mg}$ isotope composition is predicted for the observed range in $\mathrm{Sr}$ isotopes (Figure 6). Therefore, bulk sediment additions to the primitive magma or mantle source are unlikely to be the cause of the elevated $\mathrm{Mg}$ isotope compositions found in the North Cascade Arc samples.

Assimilation and fractional crystallization in the deep continental crust, on the other hand, can match the observed trends without an excessively high crustal contribution. The observed major element and isotopic trends can be reproduced with between 100 and $60 \%$ liquid remaining in the system (Figure 6). Unlike the bulk mixing models, AFC can approximate the observed increase in $\mathrm{Mg}$ isotope composition within the range of $\mathrm{Sr}$ isotope compositions exhibited by the samples (Figure 6). Given the elevated $\mathrm{Pb} / \mathrm{Ce}$ and $\mathrm{Ba} / \mathrm{Th}$ ratios, and the apparent correlation between $\delta^{26} \mathrm{Mg}$ and $\mathrm{Pb} / \mathrm{Ce}$ in these samples, fluid additions may also have made a minor contribution to the final $\mathrm{Mg}$ isotope compositions. However, quantifying the slabderived fluid effect on $\mathrm{Mg}$ isotopes is not currently possible given our limited understanding of $\mathrm{Mg}$ isotope behavior during slab dehydration. Assimilation and fractional crystallization is the favored explanation for the increase in $\mathrm{Mg}$ isotope 
composition, and while minor effects from the addition of slabderived fluids to the mantle source and primitive may have occurred, those processes are unlikely to the primary cause of the heavy $\mathrm{Mg}$ isotope compositions observed in the North Cascade Volcanic Arc.

The Mg isotope compositions exhibited by the North Cascade Volcanic Arc samples are similar to those from previously analyzed volcanic arcs (Figure 1). Li et al. (2017) analyzed arc samples from Kamchatka $\left(\delta^{26} \mathrm{Mg}=-0.35 \pm 0.05\right.$ to $-0.24 \pm$ $0.08 \%$ ) , the Philippines $(-0.19 \pm 0.05$ to $+0.06 \pm 0.04 \%$ ), Costa Rica $(-0.32 \pm 0.01$ to $-0.27 \pm 0.05 \%$ ), and Lau $(-0.26$ \pm 0.02 to $-0.16 \pm 0.05 \%$ ), while Teng et al. (2016) analyzed samples from the Lesser Antilles $(-0.24 \pm 0.07$ to $-0.10 \pm$ $0.07 \%$ ). The Cascade samples $(-0.33 \pm 0.07$ to $-0.15 \pm$ $0.06 \%$ ) have similar $\mathrm{Mg}$ isotope compositions to the samples from all of those locations except the Philippines, which have unusually heavy compositions (Li et al., 2017). The present dataset fills in a gap in the $\mathrm{Mg}$ isotope data for arc volcanics from the circum-Pacific subduction zones, representing the margin along the northwestern coast of North America. The similarity to these other arc samples, including those from the Lesser Antilles in the Caribbean, demonstrates that the processes affecting $\mathrm{Mg}$ isotopes are likely consistent from margin to margin. Much of the combined data for the volcanic arcs worldwide can be approximated by the same assimilation and fractional crystallization model used with the North Cascades samples (Figure 6). AFC processes are, therefore, the most likely explanation for the range in $\mathrm{Mg}$ isotope data observed in volcanic arcs. Small differences in the $\mathrm{Mg}$ isotope compositions of the primitive magma, subducted sediment, and assimilated lower crust between and within different arcs likely do impact the final magma composition, producing the observed variety between the arcs.

Although crustal input to the North Cascades magmas produced only small, just beyond two-sigma analytical uncertainty, variations from normal mantle values, this likely required a significant crustal addition. Nonetheless, improvements in analytical precision may make possible the use of $\mathrm{Mg}$ isotopes as a valuable tracer of crustal recycling that is complementary to established methods such as $\mathrm{Sr}-\mathrm{Nd}-\mathrm{Hf}-\mathrm{Pb}$ isotopic and trace element data. The crustal materials that may be involved in arc volcanism, including subducted sediment and sediment melt, altered oceanic crust, slab-derived fluids, and assimilated continental crust, have extremely varied $\mathrm{Mg}$ isotope compositions. This variability, along with the lack of fractionation during most high temperature processes, may permit $\mathrm{Mg}$ isotopes to be a valuable tool in tracing arc volcanic processes. With a thorough understanding of the composition of these different reservoirs, $\mathrm{Mg}$ isotope systematics, combined with existing geochemical indicators, would elucidate the nature of crustal input in a given arc. Furthermore, $\mathrm{Mg}$ isotopes may provide a solution for detecting crustal input in settings where commonly-used radiogenic isotopes are ambiguous due to lack of isotopic contrast between the crust and primary magmas (e.g., Mullen et al., 2017). These findings also represent a significant step in our understanding of the $\mathrm{Mg}$ cycle by demonstrating that silicate material from the crust can alter the isotopic composition of a magma.

\section{SUMMARY}

The main conclusions from this study are:

1. The $\mathrm{Mg}$ isotope composition of samples from the North Cascade Arc range from $-0.33 \pm 0.07$ to $-0.15 \pm 0.06 \%$.

2. The alkali basalts from the Bridge River Cones reflect the partial melting of the mantle source with minimal crustal contamination, while the calc-alkaline basalts and andesites from Mt. Baker, Glacier Peak, Chilliwack Batholith, and the Bridge River Cones do have Mg isotope compositions indicative of variable crustal contamination.

3. The samples with high $\delta^{26} \mathrm{Mg}$ are best explained by the addition of isotopically heavy deep continental crust to primitive magmas through assimilation and fractional crystallization with a possible minor contribution from slabderived fluids.

4. With further study and analytical improvements, Mg isotopes will become a useful tool in understanding the generation and evolution of magmatic rocks.

\section{AUTHOR CONTRIBUTIONS}

$\mathrm{AB}, \mathrm{F}-\mathrm{ZT}$, and EM: Contributed to the conception of the presented idea; EM: Provided the analyzed samples; AB: Performed the relevant experiments; AB: Wrote the manuscript with support from EM and F-ZT.

\section{ACKNOWLEDGMENTS}

We would like to thank Shui-Jiong Wang for his extensive help throughout this study, Florence Yuen, Khadijah Karrington Homolka, and Jiarui Zhou for their work in the clean lab, and Kwan-Nang Pang and I. Stewart McCallum for their insightful comments. P. Adam and J. Tepper are acknowledged for providing samples from the Bridge River Cones and the Chilliwack batholith, respectively. We would also like to thank Julia Ribeiro for her careful editing and Philip Pogge von Strandmann, Kristina J. Walowski, and Thomas Zambardi for their constructive comments. This work was supported by an NSF grant (EAR-17407706) to F-ZT.

\section{REFERENCES}

DePaolo, D. J. (1981). Trace element and isotopic effects of combined wallrock assimilation and fractional crystallization. Earth Planet. Sci. Lett. 53, 189-202. doi: 10.1016/0012-821X(81)90153-9

Foster, G. L., Pogge von Strandmann, P. A. E., and Rae, J. W. B. (2010). Boron and magnesium isotope composition of seawater. Geochem. Geophys. Geosyst. 11:Q08015. doi: 10.1029/2010GC003201

Gale, A., Dalton, C. A., Langmuir, C. H., Su, Y., and Schilling, J. G. (2013). The mean composition of ocean ridge basalts. 
Geochem. Geophys. Geosyst. 14, 1525-2027. doi: 10.1029/2012GC 004334

Hu, Y., Harrington, M. D., Sun, Y., Yang, Z., Konter, J., and Teng, F. Z. (2016a). Magnesium isotopic homogeneity of San Carlos olivine: a potential standard for $\mathrm{Mg}$ isotopic analysis by multi-collector inductively coupled plasma mass spectrometry. Rapid Commun. Mass Spectrom. 30, 2123-2132. doi: $10.1002 / \mathrm{rcm} .7700$

Hu, Y., Teng, F. Z., Plank, T., and Huang, K. J. (2017). Magnesium isotopic composition of subducting marine sediments. Chem. Geol. 466, 15-31. doi: 10.1016/j.chemgeo.2017.06.010

Hu, Y., Teng, F. Z., Zhang, H. F., Xiao, Y., and Su, B. X. (2016b). Metasomatisminduced mantle magnesium isotopic heterogeneity: evidence from pyroxenites. Geochim. Cosmochim. Acta 185, 88-111. doi: 10.1016/j.gca.2015.11.001

Huang, F., Chen, L. J., Wu, Z. Q., and Wang, W. (2013). First-principles calculations of equilibrium $\mathrm{Mg}$ isotope fractionations between garnet, clinopyroxene, orthopyroxene, and olivine: implications for $\mathrm{Mg}$ isotope thermometry. Earth Planet. Sci. Lett. 367, 61-70. doi: 10.1016/j.epsl.2013.02.025

Huang, F., Zhang, Z. F., Lundstrom, C. C., and Zhi, X. C. (2011). Iron and magnesium isotopic compositions of peridotite xenoliths from Eastern China. Geochim. Cosmochim. Acta 75, 3318-3334. doi: 10.1016/j.gca.2011.03.036

Huang, K. J. (2013). The Behavior of Magnesium Isotopes During Low-Temperature Water-Rock Interactions. Ph.D. Dissertation, China University of Geosciences, Wuhan.

Huang, K. J., Teng, F. Z., Wei, G. J., Ma, J. L., and Bao, Z. Y. (2012). Adsorptionand desorption-controlled magnesium isotope fractionation during extreme weathering of basalt in Hainan Island, China. Earth Planet. Sci. Lett. 359, 73-83. doi: 10.1016/j.epsl.2012.10.007

Kelemen, P. B., Hanghoj, K., and Greene, A. R. (2007). "One view of the geochemistry of subduction-related magmatic arcs, with an emphasis on primitive andesite and lower crust," in Treatise on Geochemistry, Vol. The Crust 2nd Edn, eds K. K. Turekian and H. D. Holland (Oxford: Elsevier), 1-70.

Lassiter, J. C., and DePaolo, D. J. (1997). "Plume/Lithosphere interaction in the generation of continental and oceanic flood basalts: chemical and isotopic constraints," in Large Igneous Provinces: Continental, Oceanic, and Planetary Flood Volcanism, eds J. J. Mahoney and M. F. Coffin (Washington, DC: American Geophysical Union), 335-355.

Li, S. G., Yang, W., Ke, S., Meng, X., Tian, H., Xu, L., et al. (2017). Deep carbon cycles constrained by a large-scale mantle $\mathrm{Mg}$ isotope anomaly in eastern China. Nat. Sci. Rev. 4, 111-120.

Li, W. Y., Teng, F. Z., Ke, S., Rudnick, R. L., Gao, S., Wu, F. Y., et al. (2010). Heterogeneous magnesium isotopic composition of the upper continental crust. Geochim. Cosmochim. Acta 74, 6867-6884. doi: 10.1016/j.gca.2010.08.030

Li, W. Y., Teng, F. Z., Xiao, Y. L., Gu, H. O., Zha, X. P., and Huang, J. (2016). Empirical calibration of the clinopyroxene-garnet magnesium isotope geothermometer and implications. Contrib. Mineral. Petrol. 171:61. doi: 10.1007/s00410-016-1269-1

Li, W. Y., Teng, F. Z., Xiao, Y. L., and Huang, J. A. (2011). High-temperature inter-mineral magnesium isotope fractionation in eclogite from the Dabie orogen, China. Earth Planet. Sci. Lett. 304, 224-230. doi: 10.1016/j.epsl.2011. 01.035

Ling, M. X., Sedaghatpour, F., Teng, F. Z., Hays, P. D., Strauss, J., and Sun, W. D. (2011). Homogeneous magnesium isotopic composition of seawater: an excellent geostandard for Mg isotope analysis. Rapid Commun. Mass Spectrom. 25, 2828-2836. doi: 10.1002/rcm.5172

Liu, X. M., Teng, F. Z., Rudnick, R. L., McDonough, W. F., and Cummings, M. L. (2014). Massive magnesium depletion and isotope fractionation in weathered basalts. Geochim. Cosmochim. Acta 135, 336-349. doi: 10.1016/j.gca.2014.03.028

McDonough, W. F., and Sun, S. S. (1995). The composition of the Earth. Chem. Geol. 120, 223-253. doi: 10.1016/0009-2541(94)00140-4

Mullen, E. K., and McCallum, I. S. (2013). Coexisting pseudobrookite, ilmenite, and titanomagnetite in hornblende andesite of the Coleman Pinnacle flow, Mount Baker, Washington: evidence for a highly oxidized arc magma. Am. Mineral. 98, 417-425. doi: 10.2138/am.2013.4185

Mullen, E. K., and McCallum, I. S. (2014). Origin of basalts in a hot subduction setting: petrological and geochemical insights from Mt. Baker, Northern Cascade Arc. J. Petrol. 55, 241-281. doi: 10.1093/petrology/ egt064
Mullen, E. K., and Weis, D. (2013). Sr-Nd-Nf-Pb isotope and trace element evidence for the origin of alkali basalts in the Garabaldi Belt, northern Cascade arc. Geochem. Geophys. Geosyst. 14, 3126-3155. doi: 10.1002/ggge.20191

Mullen, E. K., and Weis, D. (2015). Evidence for trench-parallel mantle flow in the northern Cascade Arc from basalt geochemistry. Earth Planet. Sci. Lett. 414, 100-107. doi: 10.1016/j.epsl.2015.01.010

Mullen, E. K., Weis, D., Marsh, N. B., and Martindale, M. (2017). Primitive arc magma diversity: new geochemical insights in the Cascade Arc. Chem. Geol. 448, 43-70. doi: 10.1016/j.chemgeo.2016.11.006

Plank, T. (2014). "The chemical composition of subducting sediments," in Treatise on Geochemistry 2nd Edition, Vol. The Crust, eds H. D. Holland and K. K. Turekian (Oxford: Elsevier), 607-629.

Pogge von Strandmann, P. A. E., Burton, K. W., James, R. H., van Calsteren, P., Gislason, S. R., and Sigfusson, B. (2008). The influence of weathering processes on riverine magnesium isotopes in a basaltic terrain. Earth Planet. Sci. Lett. 276, 187-197. doi: 10.1016/j.epsl.2008.09.020

Rudnick, R. L., and Gao, S. (2003). "Composition of the continental crust," in Treatise on Geochemistry, Vol. The Crust, eds R. L. Rudnick, H. D. Holland, and K. K. Turekian (Oxford: Elsevier), 1-64.

Salters, V. J. M., and Stracke, A. (2004). Composition of the depleted mantle. Geochem. Geophys. Geosyst. 5:Q05B07. doi: 10.1029/2003GC000597

Sun, W., and McDonough, W. F. (1989). Chemical and isotopic systematics of oceanic basalts: implications for mantle composition and processes. Geol. Soc. Lond. Special Publ. 42, 313-345. doi: 10.1144/GSL.SP.1989.042.01.19

Teng, F. Z. (2017). Magnesium Isotope Geochemistry. Rev. Mineral. Geochem. 82, 219-287. doi: 10.2138/rmg.2017.82.7

Teng, F. Z., Hu, Y., and Chauvel, C. (2016). Magnesium isotope geochemistry in arc volcanism. Proc. Natl. Acad. Sci. U.S.A. 113, 7082-7087. doi: 10.1073/pnas.1518456113

Teng, F. Z., Li, W. Y., Ke, S., Marty, B., Dauphas, N., Huang, S. C., et al. (2010a). Magnesium isotopic composition of the Earth and chondrites. Geochim. Cosmochim. Acta 74, 4150-4166.

Teng, F. Z., Li, W. Y., Ke, S., Yang, W., Liu, S. A., Sedaghatpour, F., et al. (2015). Magnesium isotopic composition of international geostandards. Geochem. Geophys. Geosyst. 39, 329-339. doi: 10.1016/j.gca.2010.04.019

Teng, F. Z., Li, W. Y., Rudnick, R. L., and Gardner, L. R. (2010b). Contrasting lithium and magnesium isotope fractionation during continental weathering. Earth Planet. Sci. Lett. 300, 63-71. doi: 10.1016/j.epsl.2010.09.036

Teng, F. Z., Wadhwa, M., and Helz, R. T. (2007). Investigation of magnesium isotope fractionation during basalt differentiation: Implications for a chondritic composition of the terrestrial mantle. Earth Planet. Sci. Lett. 261, 84-92. doi: 10.1016/j.epsl.2007.06.004

Teng, F. Z., and Yang, W. (2014). Comparison of factors affecting the accuracy of high-precision magnesium isotope analysis by multi-collector inductively coupled plasma mass spectrometry. Rapid Commun. Mass. Spectrom. 28, 19-24. doi: $10.1002 / \mathrm{rcm} .6752$

Teng, F. Z., Yang, W., Rudnick, R. L., and Hu, Y. (2013). Heterogeneous magnesium isotopic composition of the lower continental crust: a xenolith perspective. Geochem. Geophys. Geosyst. 14, 3844-3856. doi: 10.1002/ggge.20238

Tepper, J. H. (1996). Petrology of mafic plutons associated with calc-alkaline granitoids, Chilliwack Batholith, north Cascades, Washington. J. Petrol. 37, 1409-1436. doi: 10.1093/petrology/37.6.1409

Tipper, E. T., Gaillardet, J., Louvat, P., Capmas, F., and White, A. F. (2010). $\mathrm{Mg}$ isotope constraints on soil pore-fluid chemistry: Evidence from Santa Cruz, California. Geochim. Cosmochim. Acta 74, 3883-3896. doi: 10.1016/j.gca.2010.04.021

Tipper, E. T., Galy, A., and Bickle, M. J. (2008). Calcium and magnesium isotope systematics in rivers draining the Himalaya-Tibetan-Plateau region: Lithological or fractionation control? Geochim. Cosmochim. Acta 72, 1057-1075. doi: 10.1016/j.gca.2007.11.029

Wang, S. J., Teng, F. Z., Li, S. G., and Hong, J. A. (2014). Magnesium isotopic systematics of mafic rocks during continental subduction. Geochim. Cosmochim. Acta 143, 34-48. doi: 10.1016/j.gca.2014.03.029

Wang, S. J., Teng, F. Z., Li, S. G., Zhang, L. F., Du, J. X., He, Y. S., et al. (2017). Tracing subduction zone fluid-rock interactions using trace element and Mg-Sr-Nd isotopes. Lithos 290-291, 94-103. doi: 10.1016/j.lithos.2017. 08.004 
Wang, S. J., Teng, F. Z., and Scott, J. M. (2016). Tracing the origin of continental HIMU-like intraplate volcanism using magnesium isotope systematics. Geochim. Cosmochim. Acta 185, 78-87. doi: 10.1016/j.gca.2016.01.007

Wang, S. J., Teng, F. Z., Williams, H. M., and Li, S. G. (2012). Magnesium isotopic variations in cratonic eclogites: origins and implications. Earth Planet. Sci. Lett. 359, 219-226. doi: 10.1016/j.epsl.2012.10.016

Yang, W., Teng, F. Z., Li, W. Y., Liu, S. A., Ke, S., Liu, Y. S., et al. (2016). Magnesium isotopic composition of the deep continental crust. Am. Mineral. 101, 243-252. doi: 10.2138/am-2016-5275

Yang, W., Teng, F. Z., and Zhang, H. F. (2009). Chondritic magnesium isotopic composition of the terrestrial mantle: a case study of peridotite xenoliths from the North China craton. Earth Planet. Sci. Lett. 288, 475-482. doi: $10.1016 /$ j.epsl.2009.10.009
Conflict of Interest Statement: The authors declare that the research was conducted in the absence of any commercial or financial relationships that could be construed as a potential conflict of interest.

The reviewer, PS, declared a past co-authorship with one of the authors, F-ZT, to the handling editor.

Copyright $\odot 2018$ Brewer, Teng and Mullen. This is an open-access article distributed under the terms of the Creative Commons Attribution License (CC BY). The use, distribution or reproduction in other forums is permitted, provided the original author(s) and the copyright owner are credited and that the original publication in this journal is cited, in accordance with accepted academic practice. No use, distribution or reproduction is permitted which does not comply with these terms. 